\title{
Self-reported experience of hospitalized children: an integrative review
}

\author{
Experiência autorelatada da criança hospitalizada: uma revisão integrativa \\ Experiencia autoinformada del niño hospitalizado: una revisión integrativa
}

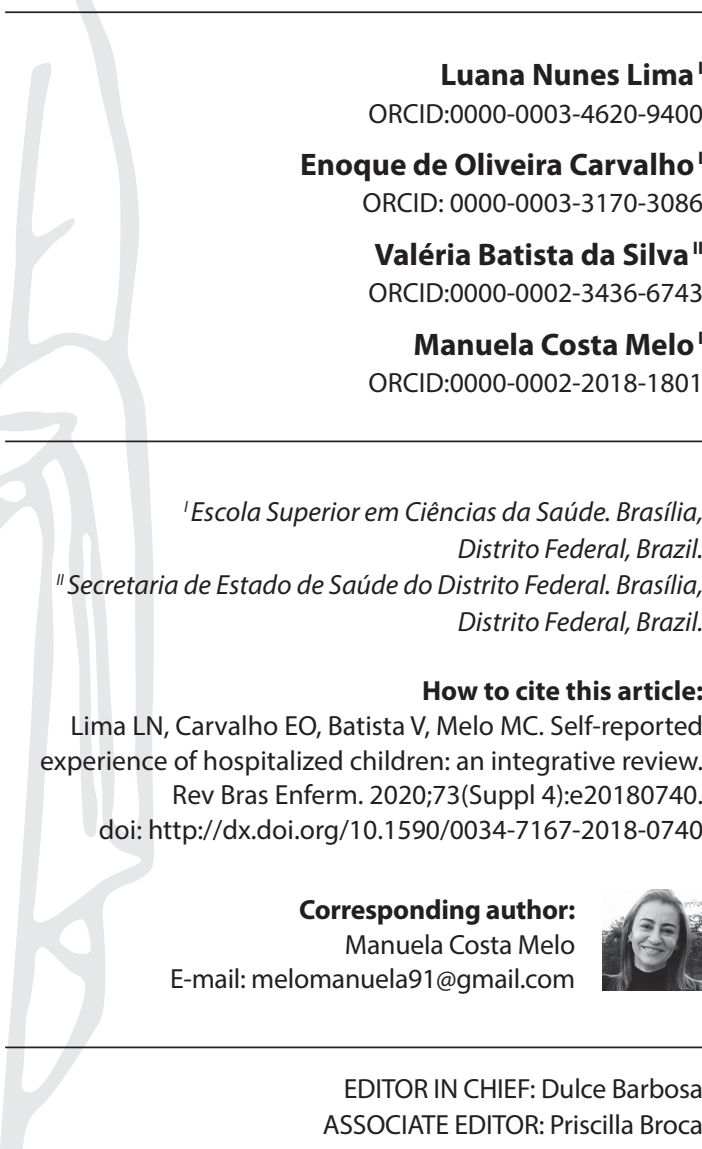

Submission: 09-18-2018
Approval: 06-26-2020

\begin{abstract}
Objective: To identify available evidence about the self-reported experience of hospitalized children. Methods: An integrative review was carried out, and the survey occurred between September and November 2017, in the electronic sources DLTD-USP, CAPES, IBICT, MEDLINE, LILACS and BDENF. Results: Ten studies were found, prevailing samples with descriptive design and approach in qualitative and mixed methods research. The literature evidenced the experience of hospitalized children through the report of parents and health professionals; few were self-reported by the child itself. Five themes were identified: Understanding the time of hospital admission, relevance of care received, feeling of pain, importance of the patient companion, information received about hospitalization. Conclusion: It was found that experiences in childhood are able to have repercussions throughout life, and it is relevant that nursing is attentive to their clients' perception in order to have more satisfaction and the negative impact is diminished.

Descriptors: Review; Hospitalization; Pediatric Nursing; Child; Child, Preschool.
\end{abstract}

\section{RESUMO}

Objetivo: Identificar evidências disponíveis sobre a experiência autorrelatada da criança hospitalizada. Métodos: Realizou-se revisão integrativa, e o levantamento ocorreu entre setembro e novembro de 2017, nas fontes eletrônicas BDTD-USP, CAPES, IBICT, MEDLINE, LILACS e BDENF. Resultados: Encontraram-se dez estudos. Prevaleceram amostras com desenho descritivo e abordagem na investigação qualitativa e mista. A literatura evidenciou a experiência da criança hospitalizada por meio do relato de pais e profissionais de saúde; escassos foram os autorrelatos pela própria criança. Identificaram-se cinco temáticas: Entendimento sobre o momento da internação hospitalar, Relevância dos cuidados recebidos, Sentimento da dor, Importância do acompanhante, Informações recebidas acerca da internação hospitalar. Conclusão: Constatou-se que experiências na infância são capazes de repercutir durante toda a vida, sendo relevante que a enfermagem esteja atenta à percepção de seus clientes para que haja mais satisfação e seja diminuído o seu impacto negativo.

Descritores: Revisão; Hospitalização; Enfermagem Pediátrica; Cuidado da Criança; Pré-Escolar.

\section{RESUMEN}

Objetivo: Identificar evidencias disponibles sobre la experiencia autoinformada del niño hospitalizado. Métodos: Se realizó revisión integrativa, y el análisis ocurrió entre septiembre y noviembre de 2017, en las fuentes electrónicas BDTD-USP, CAPES, IBICT, MEDLINE, LILACS y BDENF. Resultados: Se encontraron diez estudios. Prevalecieron muestras con dibujo descriptivo y abordaje en la investigación cualitativa y mista. La literatura evidenció la experiencia del niño hospitalizado por medio del relato de padres y profesionales de salud; escasos han sido los autoinformes por el propio niño. Se identificaron cinco temáticas: Entendimiento sobre el momento de la internación hospitalaria, Relevancia de los cuidados recibidos, Sentimiento del dolor, Importancia del acompañante, Informaciones recibidas acerca de la internación hospitalaria. Conclusión: Se constató que experiencias en la infancia son capaces de repercutir durante toda la vida, siendo relevante que la enfermería esté atenta a la percepción de sus clientes para que tenga más satisfacción y que disminuya su impacto negativo. Descriptores: Revisión; Hospitalización; Enfermería Pediátrica; Cuidado del Niño; Preescolar. 


\section{INTRODUCTION}

Studies on the history of childhood appear only at the end of the twentieth century, however it is known that in the Middle Ages the high mortality rates made children uninteresting; and in the Renaissance they were socially perceived as empty human beings to be filled by the adults of their coexistence, being still treated with indifference and as useless and expensive. In the middle of the 16th century, it was recognized the need for separation of adult life and childhood and for special treatment for childhood before integrating to adults. As a result, adults began to understand children as qualitatively different from themselves and began to feel responsible for their development, socially introducing education and initiating, through the observation and study of children, the elaboration of theories about their development ${ }^{(1)}$.

In Brazil, the population under 19 years of age corresponds to approximately $30 \%$ of hospital admissions ${ }^{(2)}$. This data becomes relevant when considering hospitalization as one of the first stressful experiences in life, which triggers perceptions of fear and anxiety and may impact the child's biopsychosocial and cultural development in a way that reflects up to the mature age ${ }^{(3)}$.

Among the possible changes promoted by hospitalization, stand out the environmental change, a family imbalance and interruption of play, means by which the child develops ${ }^{(4)}$. Furthermore, the health care environment itself is perceived as inconvenient for the child, particularly due to the phenomenon of pain, capable of negatively influencing his/her quality of life ${ }^{(5)}$. However, there are also some positive aspects such as the expectation of improvement and the comfort offered by the staff(6).

Children are aware of all the movement around them and perceive as significant the care provided by the professional staff. Nevertheless, their representation of care is not restricted to those directly related to hospitalization, such as performing procedures ${ }^{(7)}$; it permeates the hospital dynamics and reaches the daily needs, such as nourishment, physical activity, attention and affection, demands that can also be met by the patient companions ${ }^{(8)}$.

Since concerns and efforts in favor of the child's specific demands are recent ${ }^{(1)}$, a fact evidenced by national and international studies that deal with the hospitalization of children only from the perspective of patient companions and professionals ${ }^{(47)}$; and considering the high incidence of hospitalizations of the population in the aforementioned age group, a process capable of significantly altering its interaction with the environment, we have chosen the following guiding question for this study: How is the self-reported experience of the hospitalized child, according to the scientific literature?

\section{OBJECTIVE}

To identify available evidence on self-reported experience from the hospitalized child.

\section{METHODS}

\section{Design, place, and period of study}

This is an integrative review of the literature on self-reported experience of hospitalized children. This type of study is defined as a method capable of gathering, reviewing, analyzing, and synthesizing available information, with a view to making a presented subject more understandable. The data survey took place between September and November 2017.

\section{Sample and inclusion and exclusion criteria}

It was established the criteria for inclusion of publications in indexed journals: papers available in full and free of charge, published in English, Portuguese, French and/or Spanish, in the period from 2010 to 2017 and addressing the theme "experience of the child in hospital". Exclusion criteria: publications dealing with the experience of hospitalization without addressing the child's perspective, abstracts, leaflets, news reports, annals, editorials, technical documents, and duplicate studies. The time frame from 2010 to 2017 was based on the authors' intention to seek updated references on the subject in question.

\section{Study Protocol}

The design of this integrative review followed the methodological direction ${ }^{(9)}$ divided into six distinct phases. In the first phase, elaboration of the research problem, it was applied the PICOT method: P - Population; I Intervention; C - Comparison; $\mathrm{O}$ - Results; T-Time. Thus, the following structure was considered: P - children; I - hospitalization; C - Comparison; O - Results: selfreported experience; T - Time (2010 to 2017).

The second phase is the search in the literature and delimitation for inclusion of studies. The sample was selected based on the appropriate descriptors for the subject. The controlled descriptors were identified in the Bank of Descriptors in Medical Subject Headings (MESH) and in Health Sciences (DeCS); Boolean operators "AND" and "OR" were used to perform the crossings and systematize the sample collection. The terms used were: hospitalization; pediatric nurses; child care; child health; preschool child; and infant; and their correspondents in Portuguese, Spanish, and French, to serve as database search strategy. The following [databases] were used as primary sources of information: The Digital Library of Theses and Dissertations of the University of São Paulo (DLTD -USP), database of the Digital Library of Theses and Dissertations from the Coordination for the Improvement of Higher Education Personnel (CAPES) and the Brazilian Institute of Information in Science and Technology. (IBICT); the Medical Literature Analysis and Retrieval System Online (MEDLINE); the Latin American Literature in Health Sciences (LILACS); and the Nursing Database (BDENF).

In the third phase, to collect information, an instrument was elaborated to obtain from those studies the following variables: name of the author, area of expertise, title of the article, methodological characteristics of the study, language, country and year of publication. The data obtained were grouped in a table, according to thematic approaches, and interpreted based on the literature.

With the application of filters in the databases and search refinement, 277,887 studies were identified: 80 at DLTD -USP, 273,926 at DLTD - CAPES, 202 at IBICT and 3,678 at VHL. After applying the inclusion criteria, 13,728 studies were recognized: and, after applying the exclusion criteria 38 studies remained. At this stage, exploratory readings of titles and publications' abstracts were carried out in 
order to pre-select those that addressed the proposed topic. Those 38 studies were read in their entirety, of which 28 were excluded after analysis, so the sample consisted of 10 studies. The process of searching and selecting the material can be observed in Figure 1.
The study was carried out by two independent reviewers in order to follow methodological rigor and, thus, trying to reduce probable errors or biases in the evaluation of studies/interpretation of results, ensuring the results' reliability. In cases of disagreement,

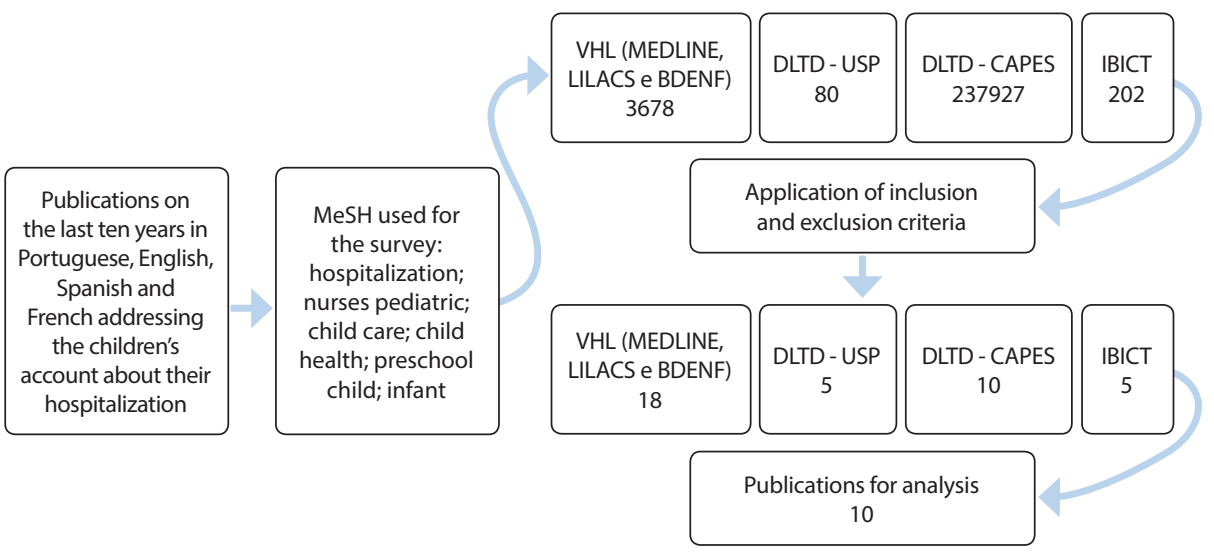

Note: VHL: Virtual Health Library; MEDLINE: Medical Literature Analysis and Retrieval System Online; LILACS: Latin American Literature in Health Sciences; BDENF: Nursing Database; DLTD - USP: The Digital Library of Theses and Dissertations of the University of São Paulo DLTD - CAPES: Digital Library of Theses and Dissertations from the Coordination for the Improvement of Higher Education Personnel; IBICT: Brazilian Institute of Information in Science and Technology.

Figure 1 - Search flow in integrative revision database

\section{Analysis of results and statistics}

This [process] was followed by the fourth phase, which corresponds to the evaluation and analysis of the elements related to the subject. It was carried out the evaluation of the identified studies and, in a descriptive manner, it was divided into five thematic categories, according to characterizing's aspects, such as hospitalization, care, pain, connection, language and learning. there was a discussion between the two reviewers and analysis by a third and fourth reviewer to reach consensus.

Based on the studies identified, the fifth phase followed by the interpretation and discussion of the results, being carried out based on the interpretation of the most relevant results. Finally, the last phase was performed, the presentation of the knowledge synthesis, in which the result of the integrative literature review was presented, with the identification of disparities and proposals for their solution in subsequent studies.

\section{RESULTS}

Chart 1 shows the distribution of publications for the final sample, which allowed visualization of relevant information, comparisons, and identification of the experience of the hospitalized child. Therefore, the sample consisted of ten studies, nine of which in the area of nursing and one in psychology, eight in qualitative research, and two, mixed methods. All were conducted in Brazil, in Portuguese, between 2011 and 2016.

Chart 1 - Distribution of the studies included in the integrative review according to the identification of the authors, professional area, title of the study, type of study, language and country of the study related to the self-reported experience of the hospitalized child

\begin{tabular}{|c|c|c|c|c|c|}
\hline Authors & Area of Expertise & Title & Type of study & Language & Country \\
\hline $\begin{array}{l}\text { CASTRO, } \\
\text { ACM }^{(10)}\end{array}$ & Psychology & $\begin{array}{l}\text { Affective aspects of pain perception in } \\
\text { pediatric, distress and quality of life of } \\
\text { hospitalized children }\end{array}$ & Qualitative and quantitative & Portuguese & Brazil \\
\hline $\begin{array}{l}\text { SCAGGION, } \\
\operatorname{LRE}^{(11)}\end{array}$ & Nursing & $\begin{array}{l}\text { But I know all: understanding the life- } \\
\text { world of hospitalized children in pediatric } \\
\text { intensive care through therapeutic toy }\end{array}$ & $\begin{array}{l}\text { Phenomenological in the light } \\
\text { of Winicott's Maturation Theory }\end{array}$ & Portuguese & Brazil \\
\hline LIMA, $J^{(12)}$ & Nursing & $\begin{array}{l}\text { The play of hospitalized children in the } \\
\text { hospital playroom }\end{array}$ & $\begin{array}{l}\text { Descriptive, cross-sectional, and } \\
\text { field-based, with a quantitative } \\
\text { and qualitative approach }\end{array}$ & Portuguese & Brazil \\
\hline LIMA, KYN(13) & Nursing & $\begin{array}{l}\text { Process of caring for children hospitalized } \\
\text { with cancer }\end{array}$ & Qualitative and descriptive & Portuguese & Brazil \\
\hline $\begin{array}{l}\text { BEZERRA, } \\
\operatorname{RS}^{(14)}\end{array}$ & Nursing & $\begin{array}{l}\text { Perception of children about care received } \\
\text { from nurses in oncology unit }\end{array}$ & Qualitative and descriptive & Portuguese & Brazil \\
\hline $\begin{array}{l}\text { PACCIULIO, } \\
\text { AM(15) }^{(15)}\end{array}$ & Nursing & $\begin{array}{l}\text { Strategies for coping with chemotherapy } \\
\text { treatment from the perspective of } \\
\text { hospitalized children with cancer }\end{array}$ & Qualitative and exploratory & Portuguese & Brazil \\
\hline $\begin{array}{l}\text { FRANÇA, } \\
\text { JRFS }^{(16)}\end{array}$ & Nursing & $\begin{array}{l}\text { Palliative care: dialogic relationship between } \\
\text { nurses and children with cancer }\end{array}$ & $\begin{array}{l}\text { Qualitative embodied in the } \\
\text { Humanistic Theory of Nursing }\end{array}$ & Portuguese & Brazil \\
\hline $\begin{array}{l}\text { QUINTANS, } \\
\text { DEB }^{(17)}\end{array}$ & Nursing & $\begin{array}{l}\text { The game of "make-believe" in therapeutic } \\
\text { toy session of hospitalized children }\end{array}$ & $\begin{array}{l}\text { Descriptive, exploratory, cross- } \\
\text { cutting and field approach with } \\
\text { qualitative approach }\end{array}$ & Portuguese & Brazil \\
\hline
\end{tabular}


Chart 1 (concluded)

\begin{tabular}{|c|c|l|l|c|c|}
\hline Authors & Area of Expertise & Title & Type of study & Language & Country \\
\hline $\begin{array}{c}\text { OLIVEIRA, } \\
\text { RBRS }\end{array}$ & Nursing & $\begin{array}{l}\text { Child pain in pediatric intensive care unit: } \\
\text { child and family perceptions }\end{array}$ & $\begin{array}{l}\text { Qualitative, exploratory and } \\
\text { descriptive }\end{array}$ & Portuguese \\
\hline $\begin{array}{c}\text { FONSECA, } \\
\text { MRA }^{(19)}\end{array}$ & Nursing & $\begin{array}{l}\text { Understanding the play of children with } \\
\text { cancer through the dramatic therapeutic play }\end{array}$ & $\begin{array}{l}\text { Qualitative from the } \\
\text { perspective of phenomenology }\end{array}$ & Portuguese & Brazil \\
\hline
\end{tabular}

The results of this review revealed that many studies were conducted based on reports from family members and/or professionals. However, there are few studies self-reporting the child's experience. It is also worth mentioning that studies on hospitalization whose participants have chronic diseases, in need of repeated and long hospitalizations, as in the case of cancer, neuropathies and other various syndromes, are more frequent than those presenting other kind of participants, such as those who experience diseases which required less time and frequency hospitalizations. The studies included in this review were classified into five thematic categories: understanding the moment of hospitalization, relevance of the care received, feeling of pain, importance of the patient companion, and information received about the hospital admission.

\section{DISCUSSION}

\section{Understanding the moment of hospital admission}

Often illness and hospitalization are the first crises faced by children. Their reactions are influenced by their age, developmental stage, environment, level of anxiety, previous experience with illness, separation or hospitalization, innate or acquired coping capacity, severity of diagnosis, available support systems and coping strategies promoted by professional staff ${ }^{(3,20)}$.

For this topic, the literature shows that hospitalized children live stressing experiences, besides fear and anxiety, being necessary to adapt to new situations by mobilizing internal resources, mostly affective and behavioral; and external resources, such as environmental resources, especially entertainment activities ${ }^{(4,10)}$. So, for the child, hospitalization is characterized as a disease, because besides physical sickness it impels great emotional disorders, which include from regression in psychosocial development to deep sadness ${ }^{(11,21)}$. However, it should be emphasized that studies identified, both in the qualitative and mixed approach, relate the social environment with the perception and child's confrontation during hospitalization, i.e. the child's reaction depends intrinsically on the reaction of the people with whom he maintains an affective connection ${ }^{(1213,21)}$.

Other studies have emphasized that hospitalization periods are capable of attacking the child's playful world, considering that they diminish both their interaction with other people and the performing of previously ordinary activities and, thus, allowing negative alterations in their development. This happens because the child's development is only possible through play and, since this activity is limited, consequently there will be implications in his/her daily life ${ }^{(22)}$. Moreover, such repercussions will be felt throughout the family system, through disagreements or even organic alterations in other members, making necessary adaptations in order to maintain the balance of that system ${ }^{(10,12-13,23)}$.
In the literature, other researches have been found, also in the qualitative approach, that reinforce the inconveniences suffered by children during hospitalization, such as pain, medication-related side effects, idleness and uncertainties, the rigidity of schedules (such as visiting and bathing schedules), the performance of invasive procedures that were done even during moments of relaxation when the child was at the toy library, and the feeling of loneliness (resulting from the absence of people with whom the child no longer has contact, such as friends, siblings, grandparents and teachers ${ }^{(5)}$. However, these researches have also evidenced that the children have verbalized in a positive way comfort, environment and food, toy library and personal hygiene, the staff care regarding body exposure and promotion of well-being ${ }^{(6,14-15)}$.

An investigation in the field of psychology has found that all these inconveniences are capable of triggering stress, which is defined by a state of tension or imbalance that causes internal ruptures in the individual's organism ${ }^{(7)}$. It is considered an organism's pathogenic reaction which occurs when the inability to respond to this demand becomes greater than the adaptive capacity; and includes physical and/or psychological symptoms, anxiety, nightmares, sudden introversion, discouragement, insecurity, aggressiveness, excessive crying, abdominal pains, diarrhea, headache, nocturnal enuresis, stuttering, inappetence and respiratory difficulty ${ }^{(10)}$. In addition, it is an intrinsic response from the human being, regardless of age, which, in addition to leaving him/her vulnerable, can trigger confused and dichotomous feelings ${ }^{(24)}$.

According to some reviewed studies, four stressful experiences lived by children during hospitalization were identified: the illness itself; the meaning the child gives to that illness, the search to develop coping strategies, and the implementation of these strategies. It is also known that same situation will not be necessarily stressful for two individuals; risks do not predict a situation, since they can be annulled if there is protection; stress can be toxic or tolerable; exposures in childhood modulate the individual's prefrontal cortex positively or negatively, making the child more susceptible to certain pathogens. Moreover, prolonged stress during childhood is related to the development of numerous diseases in adulthood, including emotional ones ${ }^{(11,15,25)}$.

Specifically in the case of cancer, the literature stated that there was social stigma related to the diagnosis, evidenced by the act of the child avoiding speaking the word cancer, by the reports of fear of dying, of the estrangement from the family, of the unknown and of what is to come, as symptoms and physical limitations; and by the anguish of observing the suffering of children also interned ${ }^{(4,16)}$.

It is worth noting that there are strategies to improve the experience of hospitalization, such as carrying out activities in the toy library; promoting care based on the provision of comprehensive health care for the child, which includes them and their patient companions in the decision-making; and addressing not only biological aspects, but also spiritual ones ${ }^{(13,15,17)}$. 


\section{Relevance of the care received}

In this topic approach, the literature has reinforced that children are always attentive to demonstrations of care, affection and warmth offered by the team of professionals and therefore choose preferred members to care for them ${ }^{(24)}$. Consequently, care ceases to be only technical and involves attributes proper to the human relationship, including the interaction of patients and their relatives with health professionals ${ }^{(13,15,17)}$.

Care is related to daily needs, such as eating, drinking, walking and playing, which are perceived through the encouragement to eat and drink water, questions regarding the child's satisfaction with the diet, anthropometric evaluations, encouragement for physical activities and the attention and availability of the health professional to listen to the children ${ }^{(8)}$. Also, the performance of procedures, attention to the schedule when medication should be taken, meeting the demands expressed by them to professionals, use of individual protection equipment by professionals, active listening, environmental infrastructure and cleaning of the unit are also evidenced ${ }^{(13-14)}$.

Revised studies have indicated that some care offered, such as the organization and pre-established time for bathing, and the performance of painful procedures, are not recognized as care by those who receive them ${ }^{(26)}$. It is also worth highlighting that some children believe that professionals feel pleasure and/ or difficulty in performing procedures such as venous access puncturing, which makes it necessary to understand the child's imaginary about the hospitalization process in order to reduce feelings of guilt and punishment ${ }^{(11,17)}$.

Considering caring as an undertaking of actions that touch the human being in his essence and focus on his/her importance, both for the human being who receives him and for the one who provides him, it is correct to say that the health care provision should be done according to the need expressed directly or indirectly by the child $^{(16)}$. Therefore, caring for the child goes beyond knowing the disease, its causes and identifying its manifestations. They want care beyond that related to the biomedical model, i.e., one that permeates the aspects linked to the stages of child development ${ }^{(10,13)}$.

The children should be listened to, have freedom of expression, point out their demands so that professionals build up an adequate care plan, capable of responding to the inferred and manifested needs ${ }^{(8)}$. Once the nursing professionals are closer to the children, it is necessary for them to know and understand technically and scientifically each phase of childhood, to be able to assist them in their adaptation, understanding and acceptance of the illness, its treatment and the phase of changes they are experiencing. The reviewed literature stresses that care is not only offered by professionals, but also by caregivers, based mainly on an interactive process that involves smiling and talking ${ }^{(10)}$.

It was identified in this review that children compare their experiences and evaluate care provision based on what they understand to be the technical-scientific preparation of those who offer it, besides the demonstration of affection, warmth, dialogue and emotional approach of the professionals ${ }^{(14,26)}$. They also assess the quality of care relating it directly to the comfort offered before, during and after the performance of procedures. Comfort may be offered through tickling, for instance. There is also a direct relationship between the children's perception of the care provided and the trust they may give to the professionals ${ }^{(13-14)}$.

\section{Feeling of pain}

Pain, especially persistent pain, can influence social and individual aspects. For its identification and evaluation, the literature has utilized standardized scales, such as Craig and Riddel's sociocommunicative model of pain, which seeks to understand it in several aspects ${ }^{(10)}$. However, a study was presented demonstrating the experience of feeling pain during hospital stay, demonstrating that stress causes greater pain perception by the child and vice-versa ${ }^{(7)}$. Children, depending on their developmental phase, are capable of not only reporting it, but also classifying it - indicating that they know their own limits - and recognize it as part of the healing and improvement process ${ }^{(14)}$. However, pain is subtracted mainly because it is not correctly evaluated and because the child's evaluation is little considered ${ }^{(19)}$. The report of hospitalized children's pain is mainly associated to the performance of some procedures, including new and repetitive ones, and the use of needles as a cause of pain has been reiterated in several studies ${ }^{(10,14)}$.

The act of dealing with and expression of pain tend to be different in each child, varying in essence according to the way the family member acts in front of him/her. A study conducted in the field of psychology has identified that the greater the intensity of pain felt by the child, the greater the stress, the lower the quality of life and greater confrontation based on the mother's search for religious practices and fanciful thoughts ${ }^{(10)}$. In another study, it was shown that relatives relate the child's pain with isolation; they believe that the longer the child is alone, isolated, without the people he/she likes, or simply without the person he/she likes the most, the pain becomes more evident ${ }^{(18)}$.

A study utilizing children stress and face's scale reviewed states that psychological therapies performed with parents and children may increase the child's tolerance and resistance to pain ${ }^{(10)}$. Furthermore, the need for interaction between professionals and children is emphasized, aiming at the correct evaluation of pain and effectiveness of non-pharmacological methods for pain relief and other discomforts felt by the child during hospitalization, such as the presence of family, music, books, paintings, movies and drawings ${ }^{(10,27)}$.

\section{Importance of the patient companion}

The reviewed studies revealed that hospitalization, in the child's perception, may represent the healthy world and the sick world ${ }^{(28)}$. In the first one, there are parents, siblings, colleagues. In the second, there are doctors, nurses and other professionals who take care of the child, the treatment, and the hospital. Those two worlds can unite or dissociate; and good and evil are attributed to their elements through the experiences they bring about ${ }^{(10,13)}$.

The literature also reinforced that children express the need for affection, attention, closeness, availability for active listening and even playing when possible, besides patience and good communication between them and the staff ${ }^{(14)}$. As such, care is identified when there is effective communication between the child and the staff. This communication is the only way to know 
the child's needs, his/her perception of his/her own experiences and the possibility of establishing an effective connection. From this, children understand that professionals are attentive to their demands and have confidence in them ${ }^{(13)}$.

Likewise, since children are critical costumers of the care received and show interest in the interaction and harmony between professionals and the patient companion, it is necessary to recognize the importance of the patient companions during hospital stay and the extension of care towards them by the staff ${ }^{(13-14,29)}$.

It is known that the caregiver already knows the child and his needs and how to satisfy them; and that the feelings of the child's family influence his perception of health and well-being, as well as his confrontation and expression of pain. Besides the personal aspects, the presence of the patient companions enable their participation in the care plan elaborated by the multiprofessional staff, as long as that care is centered on the child and his family, as suggested by multiple studies ${ }^{(10,13,16)}$. Moreover, it is emphasized the attention of patient companions to the guidelines that favor safe care, even though they do not genuinely understand and execute them ${ }^{(30)}$.

Nevertheless, since being a new place, the hospital environment, not only for the child, but also for the patient companions, must undergo necessary adaptations for the family to keep the system in balance ${ }^{23)}$. Studies have pointed out child's play as an alternative to face loneliness and isolation, as children can do it alone and the family associates the moments of children's loneliness to the worsening of their feelings of sadness, with expression of these through make-believe, imitation, drama and symbolism ${ }^{(10,17)}$.

It is necessary to emphasize that the child has the right to obtain information regarding his or her condition, but it is still controversial the attribution of the communication task, being sometimes delegated to the staff and/or to the family itself. It is also known that the child misses being genuinely heard, because he or she complains about affection and attention and states that the staff communicates only with the patient companion and vice-versa ${ }^{(15)}$. These limitations in communication generate limitations in the connection, fear of lack of acceptance and of "not being liked" by the staff and by the patient companion; and, on the other hand, they prevent the care from being provided in an effective way ${ }^{(16)}$, according to the qualitative investigation carried out in the palliative care topic.

\section{Information received about hospital admission}

This last topic addresses language development. There are individual differences both in the acquisition process and in speed and quality ${ }^{(31)}$. Consequently, this development is complex and depends on a series of factors, ranging from neuropsychological maturation, affectivity, cognitive development, to contexts in which the child is inserted ${ }^{(19)}$.

Children's studies performed in hospital admission context demonstrate the appropriation of technical-scientific language, exemplified by a specific terminology and widely used in this setting ${ }^{(32)}$. Examples of such terms are the name of drugs, devices and technical terms used specifically by health professionals. However, it is worth highlighting that when questioned about the meaning of the words they used habitually, children were unable to explain them ${ }^{(14-15,33)}$.

Recent studies on human development show that people are different in several skills and that those skills explain a large part of interpersonal variation in economic and social success, diversity that manifests itself at an early age and is influenced by the environment in which one is inserted ${ }^{(34)}$. It is also known that skills acquired at one stage of the life cycle affect learning in the next phase of life ${ }^{(19)}$.

Since the child experiences hospitalization, a completely different situation from his or her routine, it is important to realize that he or she has greater needs to understand what is actually happening ${ }^{(35)}$. More information increases the child's safety and makes it easier for them to cope. However, there are still differences of opinion about the responsibility of the caregivers and those responsible for providing this information. The literature suggested that the family should be the informant of the younger children, and the staff, through adequate language, of the older children ${ }^{(11,15)}$.

Furthermore, it should be noted that the child is in full development of his cognitive skills and, depending on the phase of development in which he/she is inserted, it is possible that, based on his/ her imagination, they experience a process of illness in which they feel guilty for being sick, a factor capable of aggravating the stress. As a Result, another reviewed study reiterates the need to listen to the child, allowing the expression of feelings and enabling their development with more quality ${ }^{(17)}$.

It is reinforced by this review that concerns about children have been very neglected, and continue to this day, also due to the fact that in common sense, on which part of the care is still based, children are seen as being unable to identify their own feelings and emotions. Moreover, it is said that they do not understand what is happening and therefore is not worth explaining; and that they will not remember that in a short time, consequently the lack of relevance in attention.

\section{Study limitations}

The results of this study were limited by the difficulty of access to protected databases, the shortage of research specifically dealing with the child's self-report, and also by the inconvenience of filtering files in some databases, since, despite the application of filters, the volume of material available and the volume of material not related to the subject were incompatible. Thus, the final sample differs exponentially, which may indicate fragility in the filters available for application in the databases.

In addition, we point out that, although the searches included studies in English, Spanish and French, only studies in Portuguese and carried out in Brazil were adequate after the application of the pre-established exclusion criteria.-

In this way, it reinforces the need for field studies that directly involve what the child thinks at the time of their hospitalization, and not just what other people involved may think about that moment. That is because, with such insight, one can understand the need to know this experience by paying attention, above all, to the experience, formation of connections, traumas, and feelings that the hospital setting exerts over the little ones.

\section{Contributions to Nursing, Health or Public Policy}

As a result of this review, the studies identified on hospitalization as a stressful event are capable of altering both the child's playful world and the systems in which it is involved. The study noted that, during hospital stay, the care, and its technical aspects, 
and those of the human relationship are the object of the child's evaluation, being interpreted even based on the connection created between the child-family-professional triad.

Meanwhile, pain, especially that caused by procedures, appears recurrently in the reports, and its evaluation and handling depend on the child's stage of development. Furthermore, the setting in which the children are inserted is capable of significantly altering their language development and learning process.

Thus, since nursing professionals are responsible for care and are in greater number in hospital units, there is a need to identify the perception of who receives the care provided by them, so that the health care will be provided with quality and enable greater satisfaction both from the costumer/patient and the staff.

\section{FINAL CONSIDERATIONS}

The studies identified highlighted that childhood experiences influence the whole process of lifelong development, including biopsychosocial and cultural aspects. Therefore, it is naive and irresponsible not to reflect on what has been offered to children, especially during hospital stays, since it is common for them to be so completely vulnerable and often spend part of their childhood or all of it in a hospital.

The present study highlighted aspects of hospitalization which, although remarkably negative in the development of the child, in the search for balance on the part of the patient companions, considering the experience stressful and capable of triggering many changes and necessary adaptations, deserve to be presented to professionals so that changes in the health care provision of care may be possible. It is worth emphasizing the importance of new studies on the subject, well traced methodologies which identify aspects of hospitalization, which make this experience, sometimes inevitable, more pleasant, in the sense of qualifying professionals for the health care of hospitalized children.

\section{FUNDING}

Research developed through support by the Research Promotion Program of the School of Health Sciences (ESCS) - Selection 2018. Notice published in DODF n. 134, of July 17, 2018. Inform n. of Case 00064-0004410/2018-31.

\section{REFERENCES}

1. Ariés P. História social da criança e da família. 2a ed. Rio de Janeiro: Guanabara, 1986.

2. Ministério da Saúde (BR). Rede Interagencial de Informações para a Saúde (RIPSA). Indicadores e dados básicos: Brasil-2012 [Internet]. 2012[cited 2017 Oct 12]:IDB-2012. Available from: http://tabnet.datasus.gov.br/cgi/idb2012/matriz.htm

3. Silva RDM, Austregésilo SC, Ithamar L, Lima LS. Therapeutic play to prepare children for invasive procedures: a systematic review. J Pediatr [Internet]. 2017[cited 2019 May 26];93(1):6-16. doi: 10.1016/j.jped.2016.06.005

4. Sposito AM, Silva-Rodrigues FM, Sparapani VC, Pfeifer LI, Lima RA, Nascimento LC. Coping strategies used by hospitalized children with cancer undergoing chemotherapy. J Nurs Scholarship. 2015;47(2):143-51. doi: 10.1111/jnu.12126

5. Costa TS, Morais AC. A hospitalização infantil: vivência de crianças a partir de representações gráficas. Rev Enferm UFPE [Internet]. 2017 [cited 2019 May 26];11(Supl.1):358-67. Available from: https://periodicos.ufpe.br/revistas/revistaenfermagem/article/ download/11916/14407

6. Sposito AMP, Garcia-Schinzari NR, Mitre RMA, Lima RAG, Nascimento LC. O melhor da hospitalização: contribuições do brincar para o enfrentamento da quimioterapia. Av Enferm. 2018;36(3):328-37. doi: 10.15446/av.enferm.v36n3.61319

7. Silveira KA, Lima VL, Paula KMP. Estresse, dor e enfrentamento em crianças hospitalizadas: análise de relações com o estresse do familiar. Rev SBPH [Internet]. 2018 [cited 2019 May 27];21(2):5-21. Available from: http://pepsic.bvsalud.org/pdf/rsbph/v21n2/v21n2a02.pdf

8. Santos PM, Silva LF, Depianti JRB, Cursino EG, Ribeiro CA. Nursing care through the perception of hospitalized children. Rev Bras Enferm. 2016;69(4):603-9. doi: 10.1590/0034-7167.2016690405i

9. Teixeira E, Medeiros HP, Nascimento MHM, Silva BAC, Rodrigues C. Revisão Integrativa da Literatura passo-a-passo e convergências com outros métodos de revisão. Rev Enferm UFPI. 2013;2(spe):3-7. doi: 10.26694/reufpi.v2i5.1457

10. Castro ACM. Aspectos afetivos na percepção da dor pediátrica, estresse e qualidade de vida de crianças hospitalizadas[Dissertação] [Internet]. Faculdade de Filosofia, Ciências e Letras de Ribeirão Preto, Universidade de São Paulo, Ribeirão Preto. 2013 [cited 2017 Oct 12]. 127f. Available http: //www.teses.usp.br/teses/disponiveis/59/59137/tde-16102013-142442/pt-br.php

11. Scaggion LRE. "Mas eu sabe de tudo": compreendendo o mundo-vida da criança hospitalizada na unidade de terapia intensiva pediátrica por meio do brinquedo terapêutico[Dissertação][Internet]. Faculdade de Enfermagem, Universidade Estadual de Campinas[Internet]. 2013[cited 2017 Oct 12]. 141f. Available http: http://bdtd.ibict.br/vufind/Record/CAMP_bc6cc1635712675f515eafc565162653

12. Lima J. O brincar da criança hospitalizada na brinquedoteca hospitalar[Dissertação][Internet]. 108f. Universidade Guarulhos. 2014[cited 2017 Oct 12]. Available http: http://tede.ung.br/handle/123456789/590

13. Lima KYN. Processo de cuidar de crianças hospitalizadas com câncer[Dissertação][Internet]. Centro de Ciências da Saúde, Universidade Federal do Rio Grande do Norte. 2014[cited 2017 Oct 12]. 135f. Available http: https://repositorio.ufrn.br/jspui/handle/123456789/19613

14. Bezerra RS. Percepção de crianças sobre os cuidados recebidos dos profissionais de enfermagem em unidade oncológica[Dissertação] [Internet]. Escola de Enfermagem, Universidade Federal da Bahia. 2013[cited 2017 Oct 12]. 170f. Available from: http: https://repositorio. ufba.br/ri/handle/ri/13965 
15. Pacciulio AM. Estratégias de enfrentamento do tratamento quimioterápico na perspectiva de crianças com câncer hospitalizadas[Dissertação][Internet]. Escola de Enfermagem de Ribeirão Preto, Universidade de São Paulo, Ribeirão Preto. 2012 [cited 2017 Oct 12]. 120f. Available http://www.teses.usp.br/teses/disponiveis/22/22133/tde-23042012-105058/pt-br.php

16. França JRFS. Cuidados paliativos: relação dialógica entre enfermeira e crianças com câncer[Tese] [Internet]. Centro de Ciências da Saúde, Universidade Federal da Paraíba, João Pessoa. 2011[cited 2017 Oct 12]. 180f. Available http: http://bdtd.ibict.br/vufind/Record/ UFPB_ae7ab7977090bbfca2838c59895f8f05

17. Quintans DEB. O jogo "faz de conta" na sessão de brinquedo terapêutico de crianças hospitalizadas[Dissertação][Internet]. Universidade Guarulhos; Guarulhos. 2016[cited 2017 Oct 12]. 65f. Available: http://hdl.handle.net/123456789/701

18. Oliveira RBSR. Dor da criança em unidade de terapia intensiva pediátrica: percepções da criança e da família[Dissertação][Internet]. Escola de Enfermagem, Universidade Federal do Rio Grande do Sul, Porto Alegre. 2011 [cited 2017 Oct 12]. 104f. Available http: https://www.lume. ufrgs.br/handle/10183/31948

19. Fonseca MRA. Compreendendo o brincar da criança com câncer por meio do brinquedo terapêutico dramático[Dissertação][Internet]. Faculdade de Enfermagem, Universidade Estadual de Campinas, Campinas. 2014[cited 2017 Oct 12]. 118f. Available from: http://repositorio. unicamp.br/handle/REPOSIP/283872

20. Hockenberry MJ, Wong WD. Fundamentos de enfermagem pediátrica. 9ed., Rio de Janeiro: Elsevier; 2014.

21. Gonçalves KG, Figueiredo JR, Oliveira SX, Davim RMB, Camboim JCA, Camboim FEF. Criança hospitalizada e equipe de enfermagem: opinião de acompanhantes. Rev Enferm UFPE. 2017;11(Supl. 6):2586-93. doi: 10.5205/reuol.9799-86079-1-RV.1106sup201713

22. Lima KYN, Santos VEP. Play as a care strategy for children with cancer. Rev Gaúcha Enferm. 2015;36(2):76-81. doi: $10.1590 / 1983-1447.2015 .02 .51514$

23. Seguin EA, Araújo LM, Cordeiro Neto MR. Uma nova família: a multiespécie. Rev Direito Amb [Internet]. 2016 [cited 2019 May 26 ];82. Available from: https://dspace.almg.gov.br/handle/11037/21807

24. Falke ACS, Milbrath VM, Freitag VL. Estratégias utilizadas pelos profissionais da enfermagem na abordagem à criança hospitalizada. Rev Contexto Saúde. 2018;18(34):9-14. doi: 10.21527/2176-7114.2018.34.9-14

25. Rosa DS. Avaliação do efeito em longo prazo do estresse neonatal causado pela separação ou privação materna em ratos sobre a expressão de comportamentos defensivos associados ao pânico[Tese] [Internet]. Faculdade de Medicina, Universidade de São Paulo. 2017 [cited 2019 May 26]. 117f. Available from: http://www.teses.usp.br/teses/disponiveis/17/17148/tde-06042018-135700/publico/DAIANESANTOSROSA.pdf

26. Emidio SCD, Morais RJL, Oliveira PNM, Bezerra RS. Percepção de crianças hospitalizadas acerca do tratamento oncológico. Rev Pesqui: Cuid Fundam. 2018;10(4):1141-9. doi: 10.9789/2175-5361.2018.v10i4.1141-1149

27. Silva TP, Leite JL, Stinson J, Lalloo C, Silva IR, Jibb L. Action and interaction strategies for the care of hospitalized children with chronic cancer pain. Texto Contexto Enferm. 2018;27(4):e3990017. doi: 10.1590/0104-07072018003990017

28. Balancieri MF, Rodrigues KR, Capellini VLMF, Reis VL. Pedagogia hospitalar: intervenções na unidade pediátrica a partir da contação de histórias. Semina: Ciên Soc Hum. 2018;39(1):53-64. doi: 10.5433/1679-0383.2018v39n1p53

29. Silva LMA, Souza VMVB. Comunicação terapêutica: desafios para o diálogo em uma organização hospitalar brasileira. Reciis Rev Eletron Comun Inf Inov Saúde. 2018;12(2):134-47. doi: 10.29397/reciis.v12i2.1372

30. Peres MA, Wegner W, Cantarelli-Kantorski KJ, Gerhardt LM, Magalhães AMM. Percepção de familiares e cuidadores quanto à segurança do paciente em unidades de internação pediátrica. Rev Gaúcha Enferm. 2018;39:e2017-0195. doi: 10.1590/1983-1447.2018.2017-0195

31. Lino AM. Olhares e narrativas de crianças hospitalizadas sobre a vida escolar. [Dissertação][Internet]. Faculdade de Educação, Universidade Federal de São Carlos. 2018 [cited 2019 May 26]. 224f. Available from: https://repositorio.ufscar.br/handle/ufscar/11228

32. Pelosi MB, Silva RMP, Santos G, Reis NH. Playful activities for the development of oral and written language for children and adolescents with down syndrome. Rev Bras Ed Esp. 2018;24(4):535-50. doi: 10.1590/s1413-65382418000500005

33. Carvalho AJA, Lemos SMA, Goulart LMHF. Language development and its relation to social behavior and family and school environments: a systematic review. CodAS. 2016;28(4):470-9. doi: 10.1590/2317-1782/20162015193

34. Rodrigues PRG. Influência social, minorias ativas e desenvolvimento moral: ensaio teórico sobre representatividade política brasileira. Psicol Soc. 2018;30:e173402. doi: 10.1590/1807-0310/2018v30173402

35. Arienti MF, Portela MVZ. A criança gravemente doente fala sobre a morte: um relato de experiência. Rev SBPH [Internet]. 2018 [cited 2019 May 27];21(1). Available from: http://pepsic.bvsalud.org/pdf/rsbph/v21n1/v21n1a13.pdf 